\title{
The University Campus in the United States-As a Designed Work to Produce Knowledge; and as an Artefact of Cultural Heritage
}

\author{
Paul Hardin Kapp \\ School of Architecture, University of Illinois at Urbana-Champaign, Illinois, United States \\ Email: phkapp@illinois.edu
}

\begin{abstract}
The university campus in the United States is a unique architectural and landscape architecture typology. Nothing like it existed until Harvard University was established in 1638. Invented during in the $17^{\text {th }}$ century by the American colonists and later developed during the American Industrial Revolution, the American campus is a community devoted to teaching and generating knowledge. It can be urban, suburban, and/or rural in form and its planning directly correlates with a university's research mission and the pedagogy of the American university system. Its buildings and landscapes are embedded with iconography, which the founding builders used to convey their values to future generations. This paper presents the history of how this designed work first emerged in American society and then evolved in ways that responded to changes that occurred in America. At the end of the $20^{\text {th }}$ century, universities conserved parts of them as cultural heritage monuments. Originally, the university campus was built to disseminate a classical education, but later, the campus was built for technical and agricultural education. By the beginning of the $20^{\text {th }}$ century, professional education and sport changed its architecture and landscape. The paper briefly discusses that while it has inspired how universities are built to teach and generate knowledge throughout the world. It concludes by reaffirming its value to cultural heritage and that it should be conserved.
\end{abstract}

KEYWORDS American university campus, conservation, pedagogy, building typology, cultural landscape

Received December 2, 2017; accepted January 12, 2018.

\section{Introduction: The American Campus in Colonial America}

There are only two building typologies the United States has ever produced-the skyscraper and the university campus. Even the word, 'campus', was developed in the US, which came from the Latin word, 'Campo', a lawn with sparsely placed trees or an open space in the town. The term was first used in the $18^{\text {th }}$ century to describe the woodland in front of Princeton University's first building, Nassau Hall. In the context of Princeton, the use of this Americanised Latin term is telling: the woodland field separated the university from the small town of Princeton, this simple outdoor space is where the world of commerce and government ends and where the world of gaining and disseminating knowledge begins (Figure 1). And here, as well as at the other original American colonial collegesHarvard University, the College of William and Mary, and Yale University - the concept of 'town and gown', a physical separation between the academy and the metropole, developed. The primary reason why the campus came into existence in this way in early America was to separate the impressionable young students, who were all male, from the profane and vulgar business of the city. In this place, the university taught them a liberal arts education, in the Roman ideal, for the career objective of being either religious or civic leaders. In some instances, such as the University of North Carolina, an entire town, located several miles away from governmental seats of power, was established for this very purpose (Coates and Coates 1985). The campus became the respite in both time and space from the sordid society of everyday American life to instruct students. By the end of the $18^{\text {th }}$ century, the university campus was a distinctively different place, incomparable to any other built civic entity in the US.

Campus planning and academic building design have always reflected the way American universities operated. 

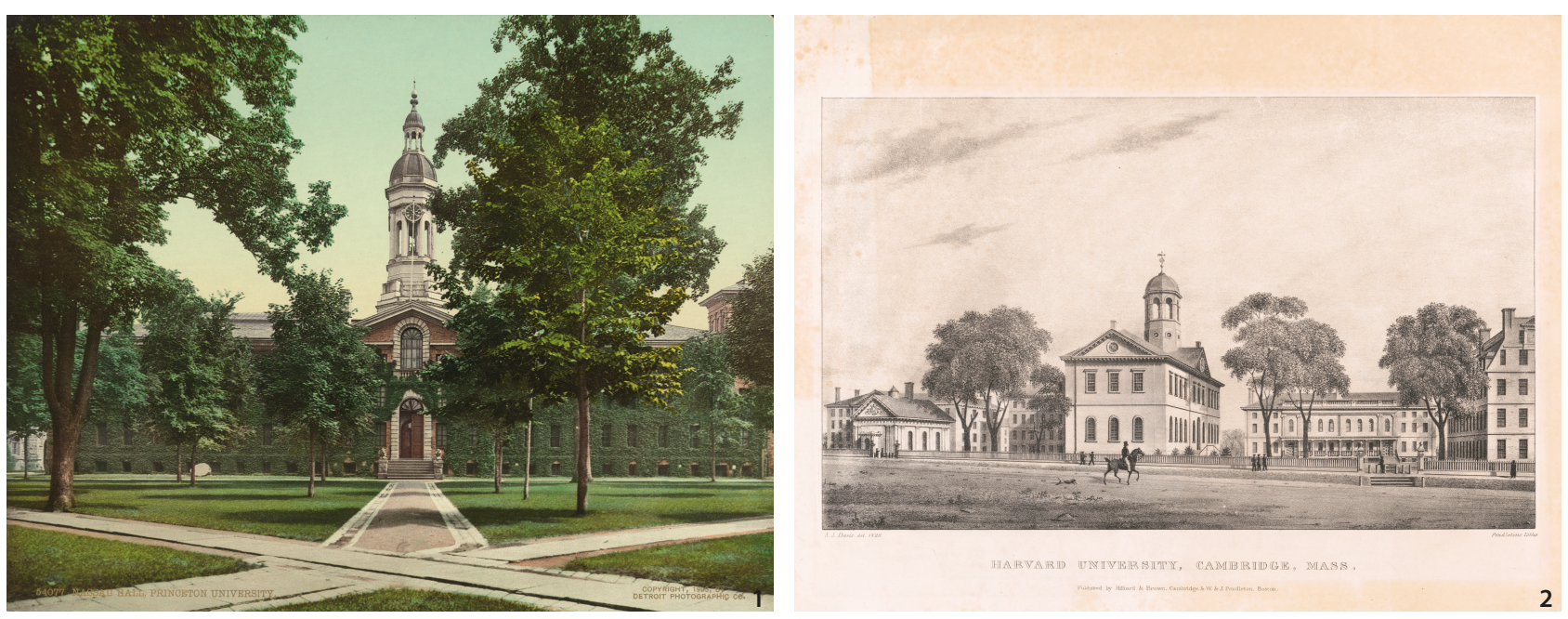

Figure 1 Nassau Hall and Front Campus, ca. 1900, Princeton University, Princeton, New Jersey (Source: US Library of Congress, Washington, DC) Figure 2 Harvard Yard, Harvard University, ca. 1850, Cambridge, Massachusetts (Source: US Library of Congress, Washington, DC).

At first, the classical curriculum (ethics and politics, arithmetic, geometry, astronomy, Greek, Latin or Hebrew, rhetoric, botany, and divinity catechetical or religion) determined both the university pedagogy and the built form of the campus (Kraus 1961). Classes were typically small and students interacted with professors in a tutorial manner. Colonial religious leaders or the Church of England founded the earliest universities, Harvard (1638), William \& Mary (1693), and Yale (1701); because of this, the earliest campuses featured a chapel or a small church for students and faculty to participate in religious services (Figure 2). During the Colonial period, purpose-built buildings, like the Wren Building (its design is attributed to the English architect Christopher Wren) at the College of William and Mary, drew inspiration in design from English manor houses, such as Banqueting House in London by Inigo Jones and Hampton Court in Molesey (which was substantially expanded through a design by Wren in the late $17^{\text {th }}$ century). Colonial American college buildings also drew inspiration from Dutch institutional buildings, such as The Hague (Kornwolf 1989). Due to financial constraints, set by the Royal colonial governments and, then later, early Republic governments, the first colleges originally consisted of a single multipurpose building, which accommodated all the tutorial rooms, the library, the chapel, and later housing for all the students. This presented numerous challenges to the well-being of the early American universities. Communal diseases spread rampant throughout the crowded buildings, fire was a constant threat and claimed several of the original college buildings, such as the first version of the Wren Building in 1705 (Kornwolf 1989)
(Figure 3). As funding and student enrolment increased, the institutions built other buildings, similar to the original multi-purpose buildings. One building campuses soon evolved into multi-building ones and a new urban space emerged-the college green, quadrangle, or square.

\section{Designing and Building the First American Campuses}

As it was said about the early Harvard campus, $18^{\text {th }}$ century American college buildings were 'built for business and nothing else' (Quincy 1860, 5). They were often two or three-story simple brick buildings with little, if any, ornamentation. Thomas Jefferson criticised the early American college campus (he was an alumnus of the College of William and Mary) 'as always ugly, inconvenient, exposed to accident in case of fire, and bad in cases of infection' (Jefferson 1805). Jefferson felt very strongly about how essential a college education was for an emerging democratic society where 'the people are the only safe depositories of their own liberty' (Jefferson 1805).

From 1817 until his death in 1826, Jefferson built his own vision of an American university, the University of Virginia. By designing a campus comprised of a system of houses for students and one for professors, he developed an ideal architectural metaphor for his tutorial-based pedagogy. In his utopian community that he described as an 'academical village', the grassy 'lawn' in the centre of the complex represents a neutral space for the students and teachers, where knowledge can be shared (Purini 1984). He also established sectarianism at Virginia, as evidenced in the omission of a chapel in his campus design (Woods 1985). It was Jefferson who first conceived of the 


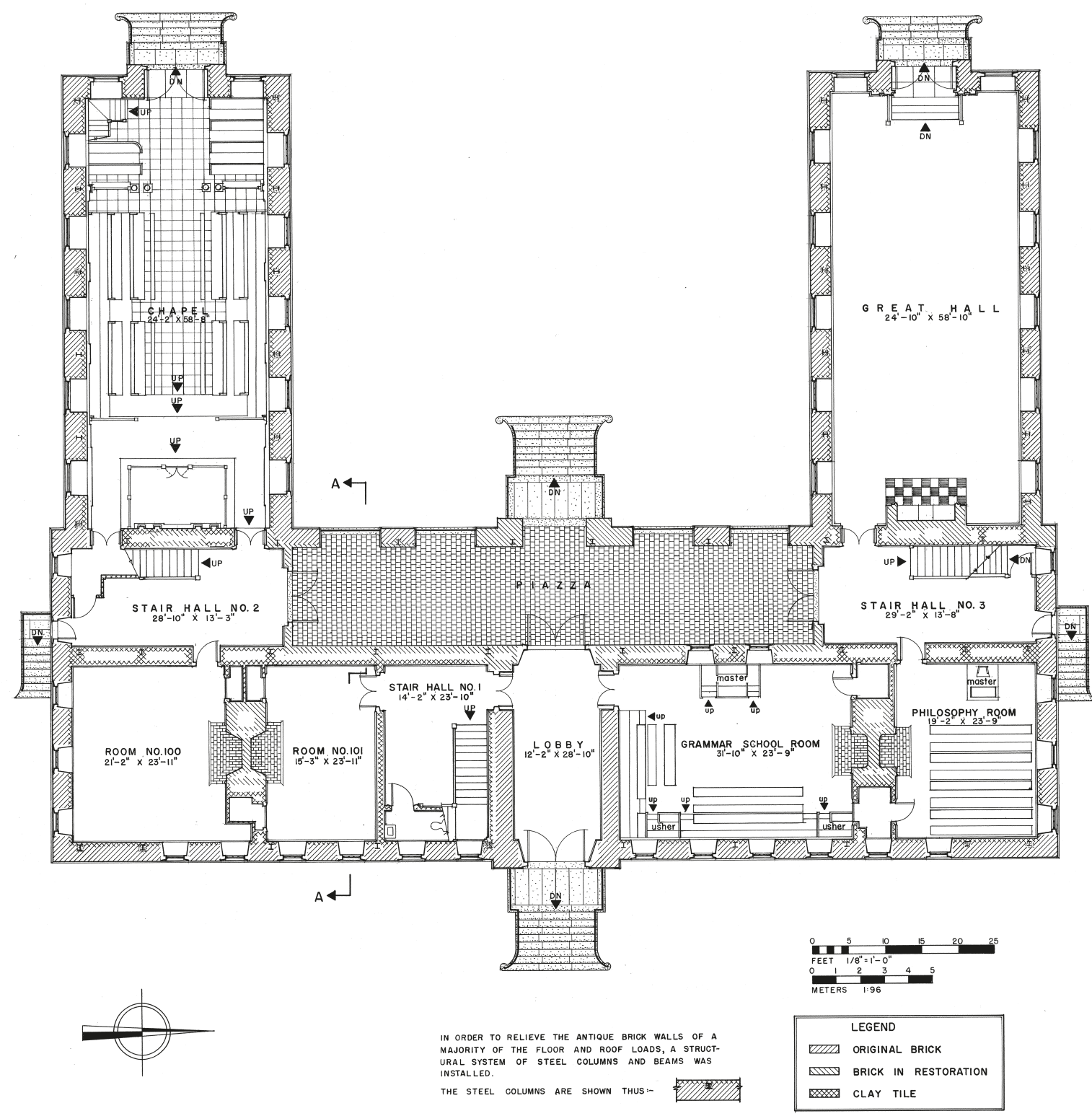

Figure 3 Wren Building, First Floor Plan, College of William and Mary, Williamsburg, Virginia (Source: Historic American Buildings Survey, U.S. Library of Congress, Washington, DC).

American university as a planned, self-contained complex, in which various components of the university were separated, such as, housing, teaching, and research. However, Jefferson did retain a vital component of the earlier campuses, the common purposed-built quadrangle, or as he referred to it-the Lawn (Wilson 2009) (Figure 4).

Jefferson also changed the architectural form of the campus. Expressing his sense of architectural symbolism, he aspired to link his University of Virginia campus buildings to the great monuments of Roman antiquity, specifically prescribed by a $16^{\text {th }}$ century architect, Andrea Palladio. The architectural orders of the ten pavilions, which comprise his academic village, are based on Temple of
Fortuna Virilis, the Baths of Carcalla, and the Theatre of Marcellus (to name but a few) (Figure 5). His library, the Rotunda, was based on the Pantheon; but in it, he transforms it from a religious temple to a temple of learninga library. By foregoing the stucco rendering, often applied over brick for institutional buildings during the 18th and early 19th centuries, Jefferson celebrates the red brick of his native land. Finally, he sought to instill an inspirational symbolism within his campus design. By placing the centre of knowledge (the Rotunda) at the northeast end of the Lawn, he grounded civilisation's source as being from the east and Europe; by keeping the southwest end of the Lawn open, he aspires a connection to the American West 


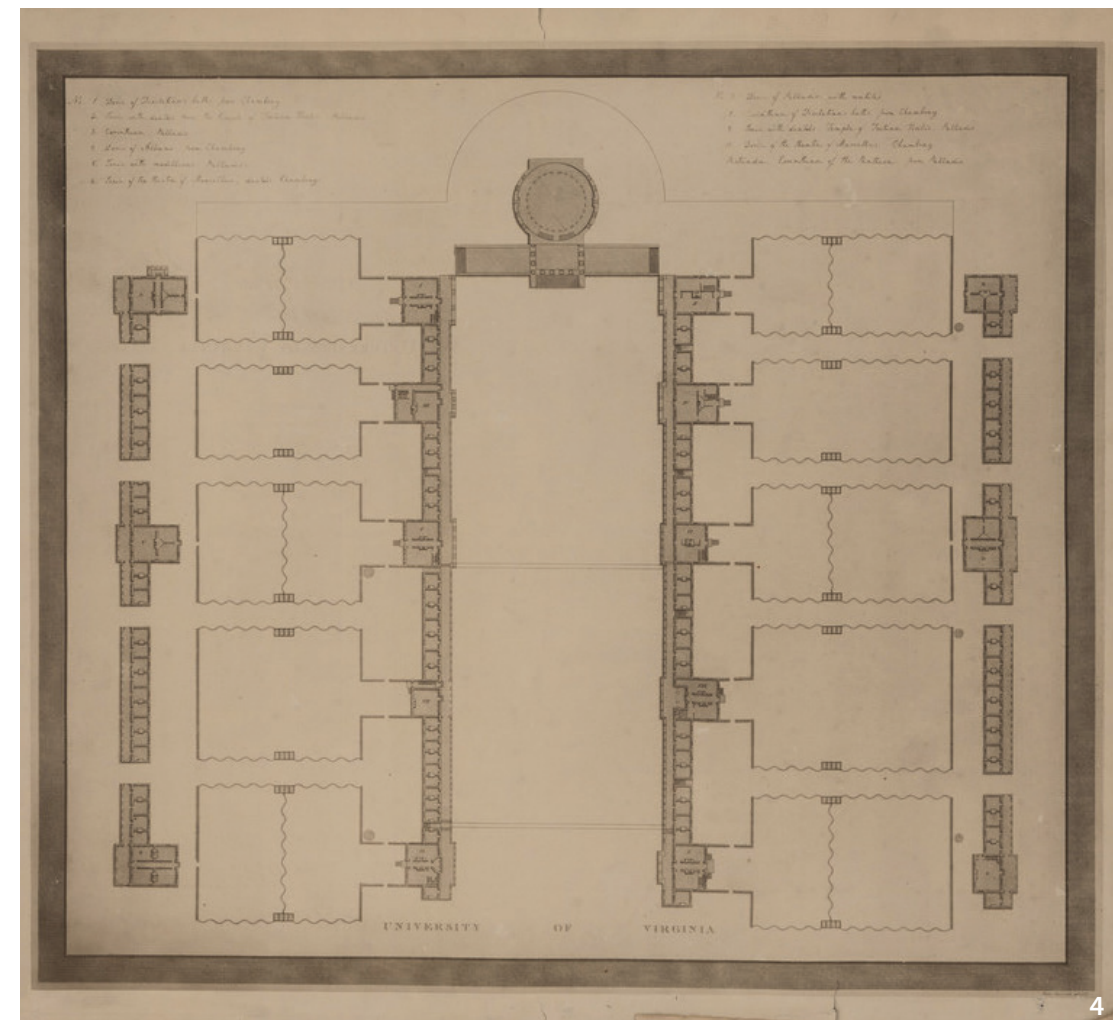

Figure 4 Site plan of the Academical Village, University of Virginia, Charlottesville, Virginia, delineated by Peter Maverick, 1826 (Source: University of Virginia Archives, Charlottesville, Virginia).

Figure 5 Pavilion III, Front façade, University of Virginia, Charlottesville, Virginia (Source: Historic American Buildings Survey, US Library of Congress, Washington, DC).

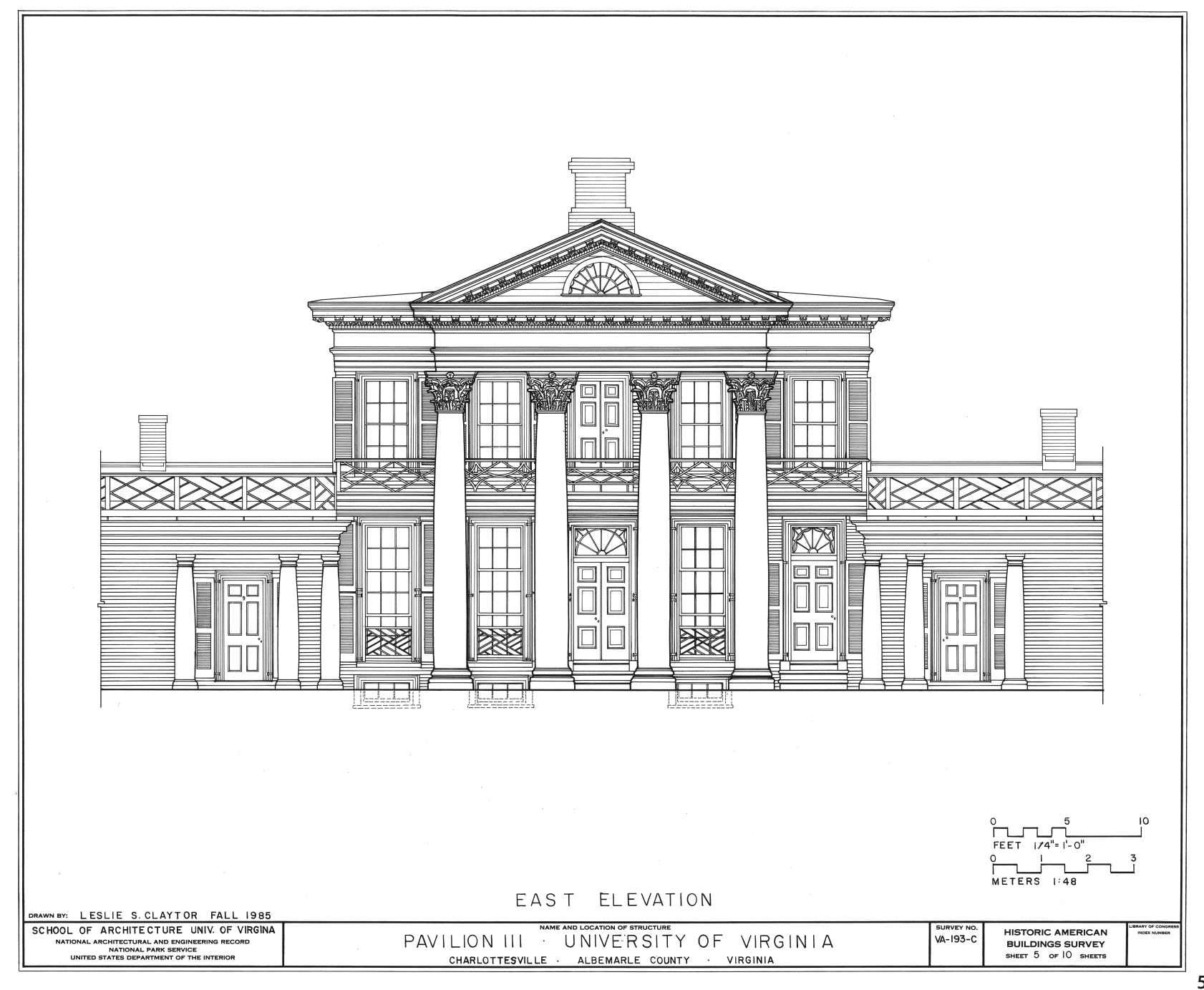


and the country's destiny to populate North America (Figure 6).

Jefferson's ideas for building a college campus made a profound and immediate impact on campus architecture throughout the US. The Board of Trustees of the University of Alabama formally asked Jefferson for a copy of his plan for the University of Virginia and explicitly emulated it in their campus design built in 1832. In 1810, even before Jefferson began building the Virginia campus, the Board of Trustees of the University of Tennessee (then known as East Tennessee College) also requested his advice regarding the planning of its campus (Kapp 2015). The campuses of the Universities of North Carolina, Georgia, and Mississippi were also influenced by Jefferson's ideas. Jefferson's protégé, Robert Mills, designed the campus of South Carolina College, now the University of South Carolina, and it had its own distinctive lawn, now known as the 'horseshoe' (Bryan 1976). These early university campuses were all 'academic villages', as Jefferson envisioned.

By the 1840s, campus design was established as both a building and planning typology in the US; however, with the passing of the American republic's founders and with a new American generation of leaders taking control of the American university, new pedagogical ideas emerged, as well as new architectural building styles and new building technologies. These factors compelled the American campus to evolve substantially before the advent of the American Civil War. The sciences became a more prominent aspect both in research and pedagogy at American universities. Observatories, beginning at the University of Michigan, became freestanding buildings, tangentially associated with the rest of the campus. Chemical and physical laboratories soon followed. As early as 1826, Jefferson designed a medical autopsy building for the Virginia campus. By 1860, diversification of functions emerged on the campus. Specific buildings, built for a singular purpose, became the norm, from Harvard to the University of Mississippi.

Building design for American university campuses soon reflected the Victorian tastes of the American antebellum period. The 'picturesque romantic' ideal in architecture, which emphasised a balance of composition over mathematical symmetry, became popular. Famed American architect, Alexander Jackson Davis, had a profound influence on several prominent university campuses, beginning with Yale, soon followed with his designs for Davidson College in North Carolina, the Virginia Military Institute, the University of Michigan, and the University of North Carolina (Peck 1992). Along with introducing a more picturesque composition of a campus layout, Davis also introduced different, more exotic building styles, such as the Gothic Revival and the Italianate style. This stylistic shift was pervasive throughout the rest of the $19^{\text {th }}$ century (Peck 1992). Even campuses, which were originally designed in the Neoclassical, bilaterally symmetrical manner, such as J.J. Ramée's Union College in Schenectady, New York (designed in 1813), would build their buildings in the 'Collegiate Gothic' style (Pierson 1970, 324-325) (Figure 7).

\section{The Morrill Land Grant Act and the Making of the American Science-Based University Campus}

During the American Civil War, a federal statute forever changed university education and campus design in the US. The Morrill Land-Grant Act of 1862 (also known as the College Land-Grant Act) was the result of movement begun twenty years earlier by Professor Jonathan Baldwin Turner of Illinois College in Jacksonville, Illinois to establish scientific-based universities, which taught agriculture and engineering, instead of only the liberal arts classical curriculum. Michigan mandated that an agricultural university be established in its 1850 constitution. The Agricultural College of the State of Michigan, known today as Michigan State University, was established in 1855. In 1857, Vermont congressman Justin Smith Morrill proposed legislation in which the US federal government provided each state a large parcel of land in that state, a land grant, to fund the building and establishment of an agricultural-based university. The US Congress passed the bill in 1857 but President James Buchanan vetoed it. Morrill re-introduced the bill in 1861, amending it to include 'providing military tactics' (military instruction) at each land-grant university, along with engineering and agricultural training. With the ongoing American Civil War proving that there was a dire need for trained officers in the field and the rise of the Industrial Revolution proving a demand for engineers, specifically, with the building of the Transcontinental Railroad, the bill passed in Congress and was signed into law by Abraham Lincoln in 1862.

It was not until after the American Civil War that land-grant universities were built. Initially, these new universities reflected the country's need to train engineers, military officers, and introduce science-based agriculture to farmers for a rapidly industrialised America. In 1865, philanthropist Ezra Cornell sought to establish a university for the state of New York that balanced the 


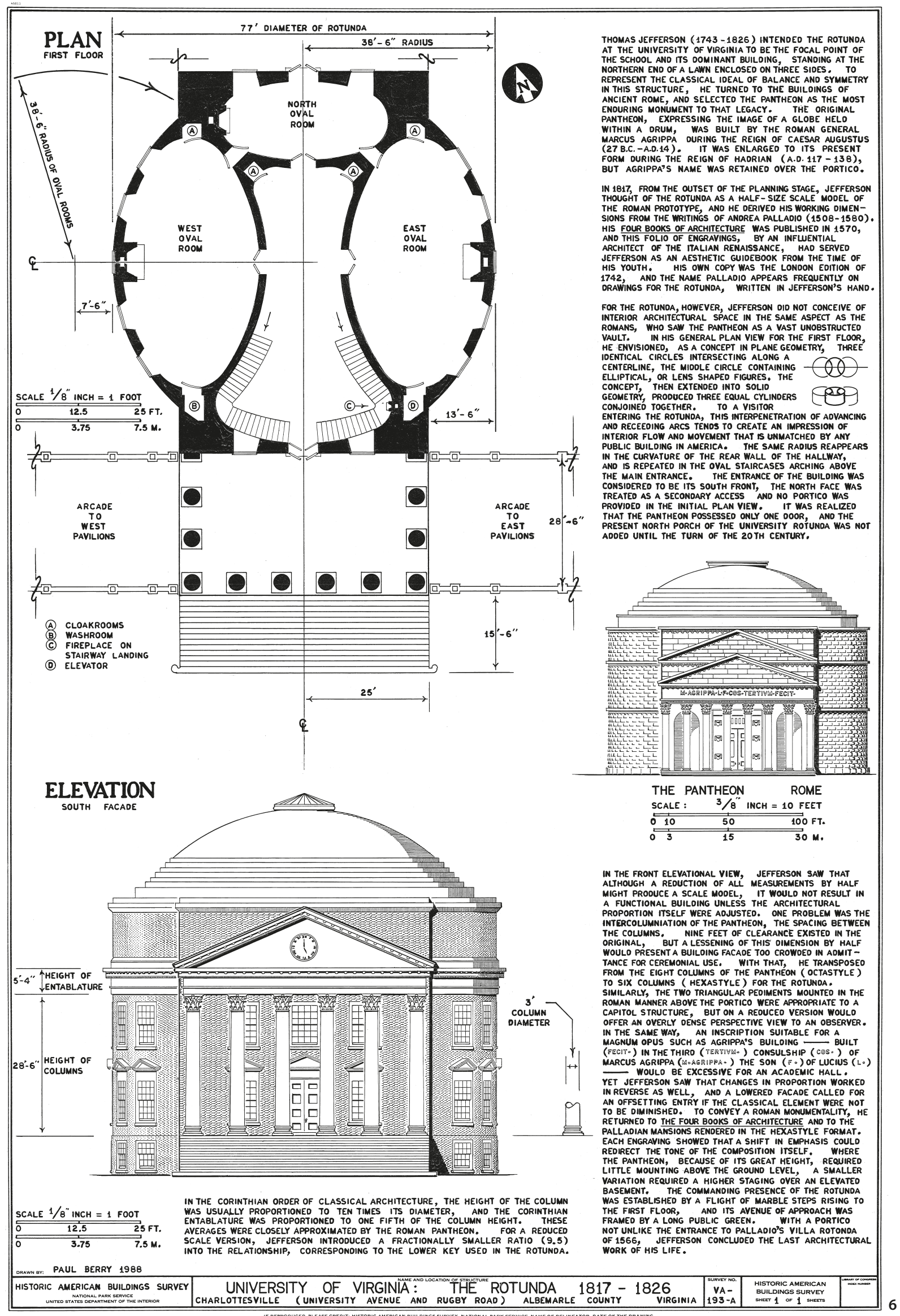

Figure 6 The Rotunda, University of Virginia, Charlottesville, Virginia (Source: Historic American Buildings Survey, US Library of Congress, Washington, DC). 

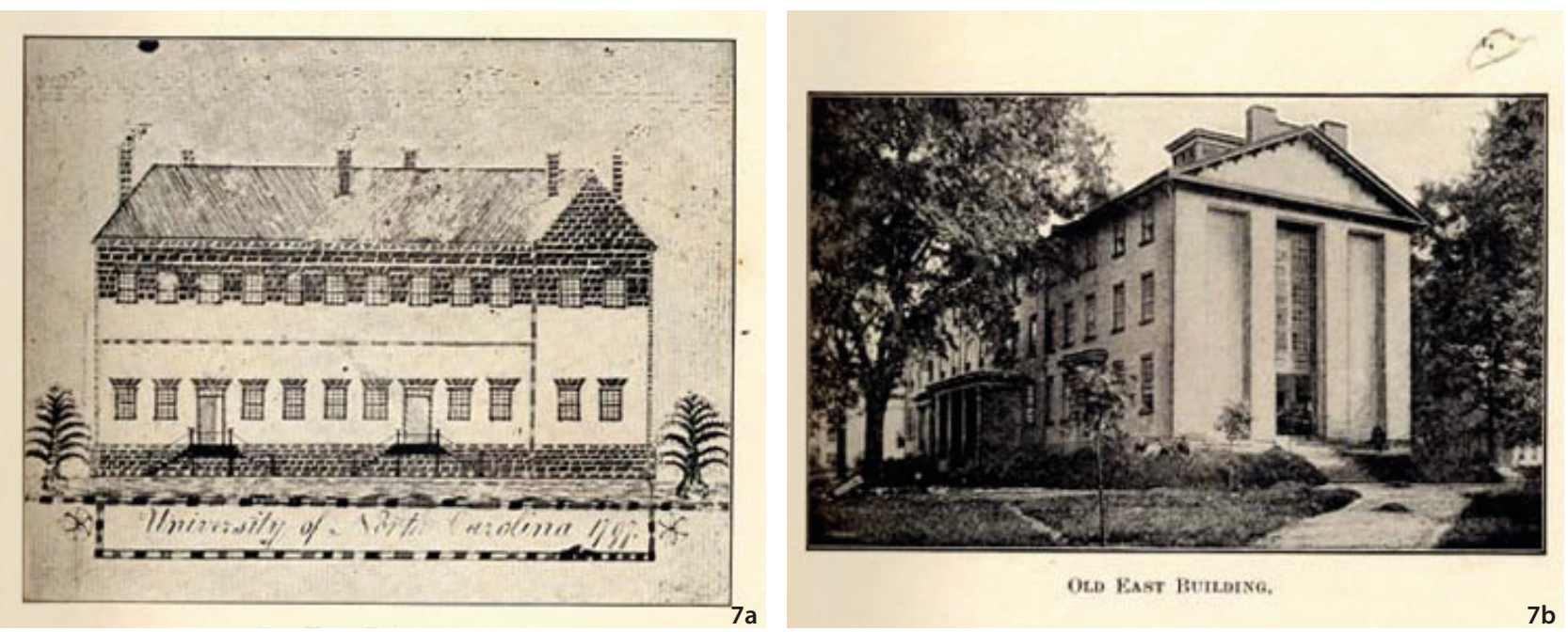

Figure 7a Old East, University of North Carolina, Chapel Hill, North Carolina. The drawing depicts how Old East appeared when it was first built in 1795 (Source: The University of North Carolina Archives, Chapel Hill, North Carolina).

Figure 7b Old East, University of North Carolina, Chapel Hill, North Carolina. The photograph, taken in 1880, depicts the northern addition designed by Alexander Jackson Davis in 1842 (Source: The University of North Carolina Archives, Chapel Hill, North Carolina).

classical liberal arts curriculum with the new industrialbased one, being developed for the new Land-Grant universities. In building Cornell University in 1865, he envisioned a dual-purpose campus and community that would require flexible extendible plans, which would allow new research and pedagogical ideas to emerge and evolve in the university (Parsons 1968) (Figure 8). In some states, the Morrill Act mandate was literally accepted and land-grant universities, such as Texas A\&M University, Iowa State University, and Kansas State University, were built exclusively for the land-grant mission. Other states merged the concept into their existing universities. In 1867, Illinois legislature directed the first board of trustees for the Illinois Industrial University 'to teach, in the most thorough manner, such branches of learning as are related to agriculture and the mechanic arts, and military tactics, without excluding other scientific and classical studies' (Kruty 1990, 4-7). By 1886, the state of Illinois would change the name of their land-grant university to the 'University of Illinois' to reflect the ever growing dynamic of university education and research, most notably within the balance between a liberal arts education and a technical one.

The campuses of land-grant universities were different than the campus designs of the original institutions of higher education that had been founded in the US before the American Civil War. The most striking distinction in their form was the result of what these universities taught. Teaching and research in agricultural sciences required a tremendous amount of land. The size of a typical American land-grant university was approximately 3,000 to
6,000 square imperial acres; far larger than comparable European agricultural universities, such as the Royal Agricultural College, which were only a fraction of that size, approximatively 80 imperial square acres. In states like Illinois, Kansas, Iowa, and Texas, comprehensive landgrant universities were established in the rural areas of the state. While other states, North Carolina (North Carolina State University in Raleigh, NC), Wisconsin (University of Wisconsin in Madison, WI), and Ohio (Ohio State University in Columbus, $\mathrm{OH}$ ), established their land grant universities in their state capitals. The 'capital city' land grant universities still required tremendous acreage but by the latter half of the $19^{\text {th }}$ century, the need for farmers to politically influence legislatures outweighed the need to provide a purer spiritual environment for impressionable young minds (Figure 9). Other states took a different tact, separating agricultural and military sciences from engineering, and thus they developed two different universities. Massachusetts established the Massachusetts Institute of Technology (MIT) for engineering sciences in 1861 near Boston and, two years later, founded the University of Massachusetts at Amherst for agricultural sciences. In 1868, California established the University of California at Berkeley, near San Francisco, for engineering sciences, and the University of California at Davis, first known as the 'University Farm' in 1908 in the fertile Sacramento Valley (UC Davis 2016). In Georgia, the Georgia Institute of Technology (Georgia Tech), was established in Georgia's capital city in 1885 and became the engineering university for the state and the agricultural mission was assigned to the originally classical-based University of 

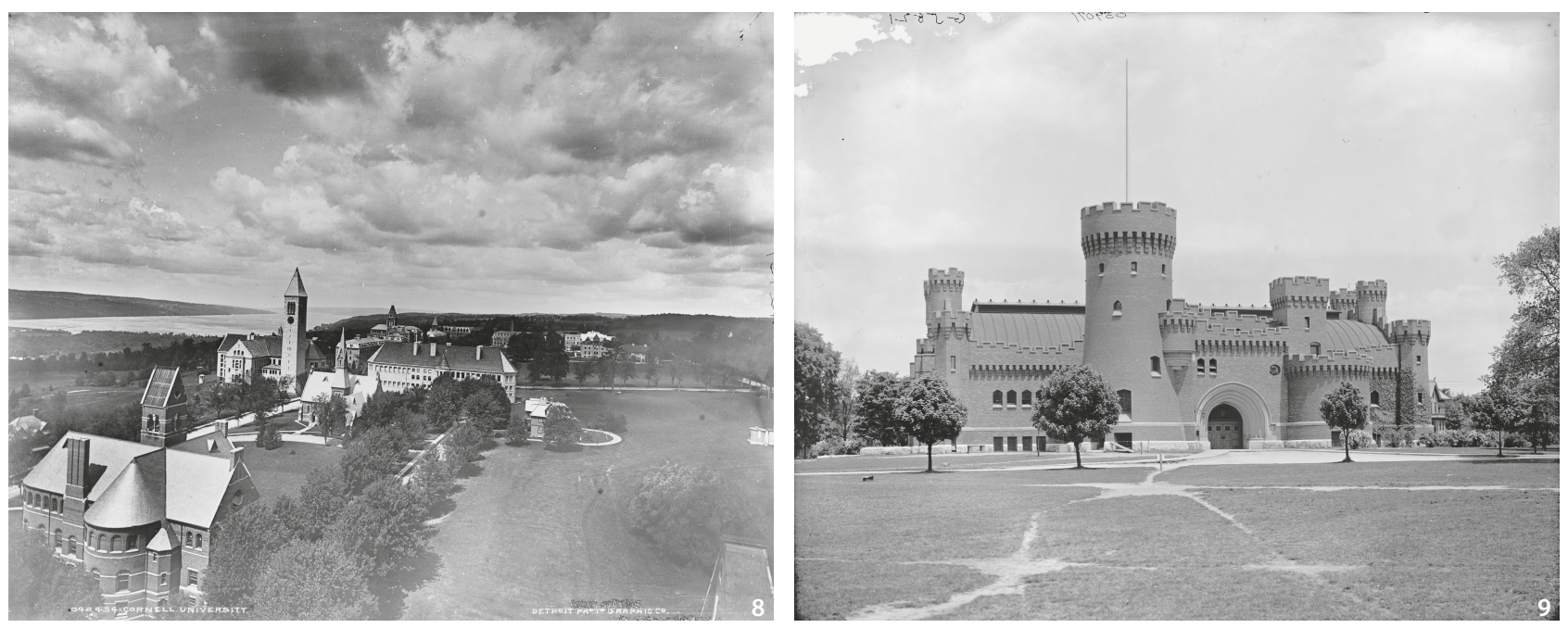

Figure 8 The Arts Quadrangle, circa 1900, Cornell University, Ithaca, New York (Source: US Library of Congress, Washington, DC).

Figure 9 The Armory, circa 1900, Ohio State University, Columbus, Ohio (Source: US Library of Congress, Washington, DC).

Georgia, charted in 1785 .

During the 100-year period between the American Civil War and the American Civil Rights era, separate universities, for both the classical liberal arts education and the new polytechnic one, were established for AfricanAmerican students. 'Separate but Equal' accommodations were mandated by the US Supreme Court ruling, Plessy versus Ferguson in 1896. This clarification of the law dictated that although American white and AfricanAmerican races were to be separated, each race should have equal spaces and opportunities, such as, a university education. African-American colleges and universities, now known as 'Historically Black Colleges and Universities (HBCU's), were predominantly established in the American South, where racial segregation was institutionalised. Some of these universities, like North Carolina A\&T University and Grambling University in Louisiana, were financially supported by the state governments; while the leading HBCU's were privately supported, such as Morehouse College in Atlanta, Georgia, Tuskegee Institute (now University) in Alabama, and Howard University in Washington, DC. Due to lack of financial support, initial campus design and construction of these universities was often simple. Faculty designed the buildings and grounds and students often built the buildings. In some instances, new universities converted a historic residence or a farmstead into a campus. In Baltimore, Maryland, Morgan State University originally began within the farm outbuildings of an $18^{\text {th }}$ century plantation. As these universities began to flourish, they built comparable buildings to their white counterparts. At Howard University, Founders Library was based on the iconic Independence Hall in Philadelphia. At Morehouse College, the late $19^{\text {th }}$ century architecture was also built in the Second Empire style, like nearby Georgia Tech.

During the 1960s, HBCU's began to be more audacious in redesigning their campuses than their white counterparts. The initial years of the Civil Rights era in the US brought about a sense of optimism for African-Americans. Leaders of HBCU's sought out to redefine the American university campus to embrace the idea of a place to educate a new generation of African-Americans who were upwardly mobile in their social class and professional métier. Modernist architecture, specifically Brutalism, became the preferred architecture for new buildings, such as Tuskegee's Chapel, designed by Paul Rudolph and inspired by Le Corbusier's Notre Dame du Haut at Ronchamp.

The most daring redesign of a HBCU campus was for Tougaloo College, located outside of Jackson, Mississippi. Originally developed from a $19^{\text {th }}$ century farmstead, Tougaloo College sought to develop their campus into a futuristic university setting. The college commissioned modernist architect, Gunnar Birkerts, who designed literally a concrete campus in the sky. Mounted on concrete piers, long bar shaped precast concrete modular buildings inter-locked with each other. From an aerial point of view, the entire campus design resembled a woven fabric. On the ground, the campus developed an interesting juxtaposition of exterior and interior spaces. As was the case at most HBCU's, Tougaloo was unable to suitably finance the entire campus design. Today, the campus design remains incomplete (Sisson 2017) (Figure 10). 


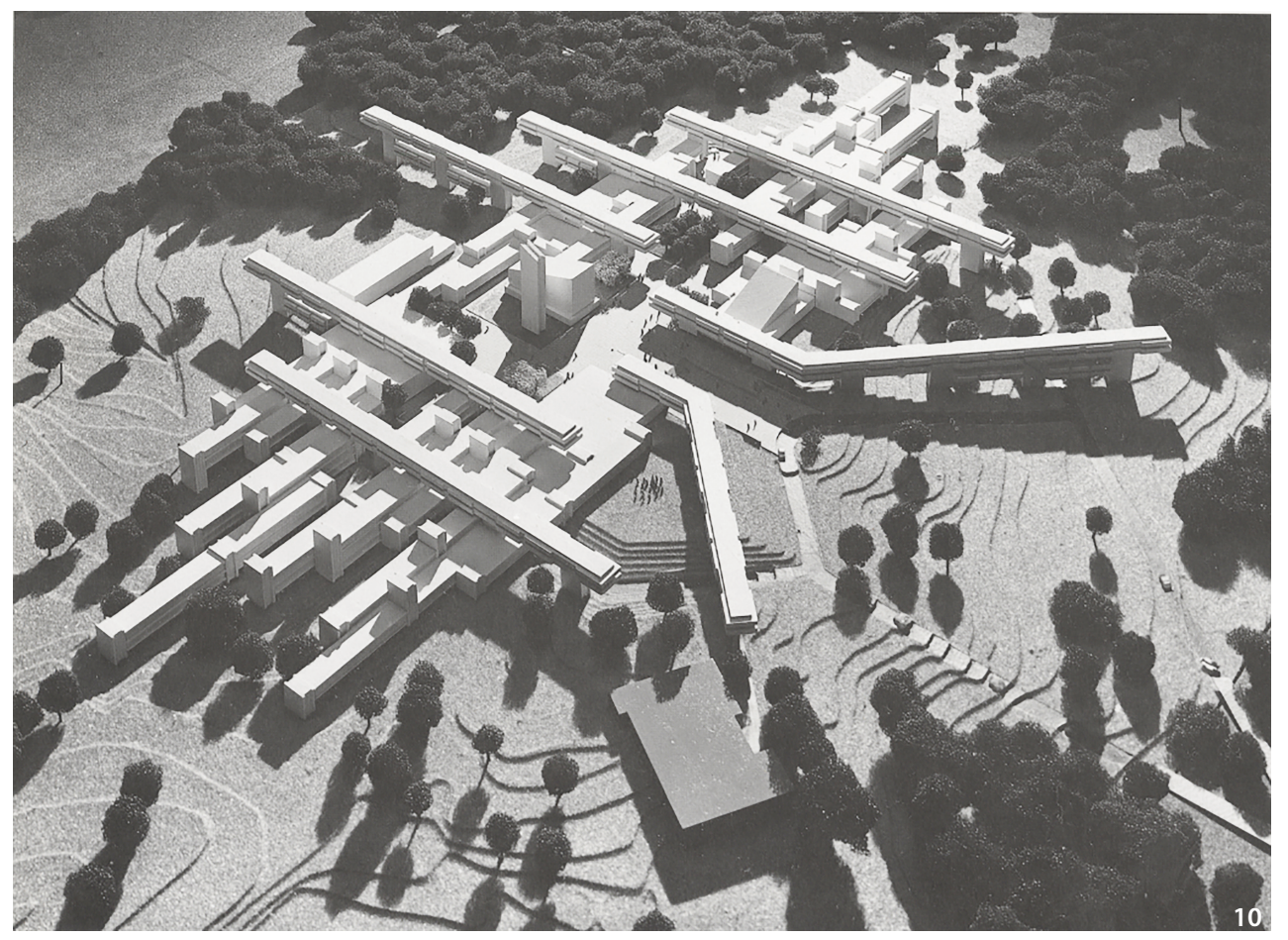

Figure 10 Proposed Campus Design of Tougaloo College, Tougaloo, Mississippi, Gunnar Birkerts, Architect, 1965 (Source: GA Architect, Gunnar Birkerts and Associates).

\section{Building the Modern American University}

Industrialisation and democratisation significantly changed American universities at the end of $19^{\text {th }}$ century. Older, established universities grew both in physical size and enrolment and new universities, introduced by the Morrill Land-Grant Act, were established and grew rapidly. Politics played a significant role in their founding and location. Site selections for these new campuses in the US were never deliberately planned. Often, the campus site selection was the result of political circumstances, which pitted regional political factions within a state against one another. These initial decisions impacted the development of these kinds of universities from their establishment to their present day. A good example can be found at the campus of the University of Illinois in Urbana-Champaign. When the University of Illinois was established in 1867, the Illinois legislature determined that it would be in the central part of the state. As architecture professor Thomas E. O'Donnell described the campus in 1929:

The setting of the infant institution offered little in the way of opportunities for development into a distinctive university campus. It possessed nothing of natural beauty-in fact it was not even interesting. No one would have deliberately selected it as a site for a great university...The only redeeming aspect was in the great free and level expanse of the open country-the majestic sweep of the Illinois prairie-which fairly invited growth and development (O'Donnell 1929, 31).

The end of the $19^{\text {th }}$ century was also a time of great architectural change for the American campus. The iconic Columbian World's Fair Expedition of 1893 in Chicago re-invigorated not only urban design in the US but also the idea of the college campus being a formal and distinct place. Beaux Arts influenced large green spaces were brought back to the campus design, throughout the US, along with neo-classical designed buildings. McKim, Mead and White's redesign of the University of Virginia, along with noted architectural historian Fiske Kimball's scholarship, re-introduced the country to the architecture of Thomas Jefferson. Stanford White of McKim, Mead \& White designed a relocated Columbia University from mid-town Manhattan to Harlem in New York that was based on Jefferson's ideas in 1900. White later designed New York University in Washington Heights in the same way. The University of Illinois, Syracuse University, and, later, Duke University built their own version of Jefferson's rotunda, but as an auditorium, not as a library. The iconographical power of building as a homage to Jefferson's Rotunda, and, through that meaning, the Roman Pantheon, was matter of great importance to both the architects and the leaders of universities on many American campuses throughout the first half of the $20^{\text {th }}$ century (Alcott 1986).

After the First World War, two developments occurring at American universities had another far-reaching influence on the physical character of the campus-professional 


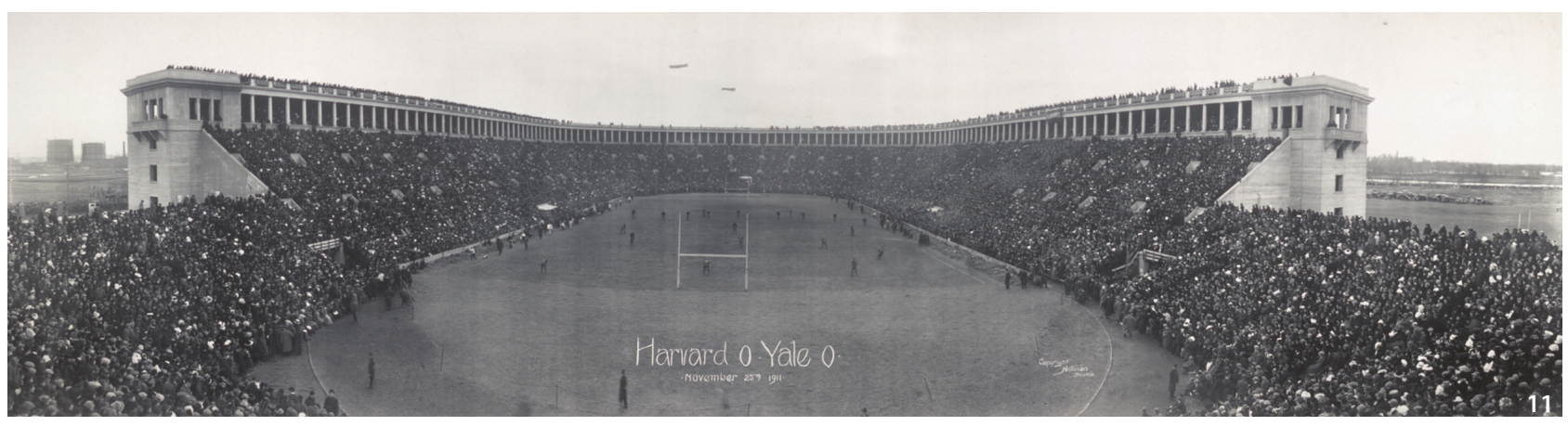

Figure 11 Harvard University Stadium, Harvard University, Cambridge, Massachusetts, 1911 (Source: US Library of Congress, Washington, DC).

training and varsity athletics, also known in the US as sports. Professional training in law, education, medicine, veterinary medicine, journalism, primary education, and architecture required buildings built exclusively for these purposes. These professional colleges were built adjacent to spaces dedicated to liberal arts, agriculture, and engineering. Intercollegiate sporting competition among universities also changed the physical character of the American campus. In 1869, Princeton University played Rutgers University in the first intercollegiate American football game. The sport gained popularity, first on the East Coast and then spreading westward. The Roman Coliseum inspired Harvard Stadium was built in 1903; due to the budget set by the Harvard Board of Trustees, the field dimensions of the sport were mandated (Figure 11). The building of Harvard Stadium, then the Yale Bowl, legitimised American football as a large crowd-attracting event on university campuses (Harvard 2016). Alarmed by the lack of physical fitness of American soldiers during the First World War, sporting activities, such as football and basketball, were promoted at American universities with the intent to keep young men in good shape in the event of an armed conflict. This led to the building of more large football stadiums and basketball arenas at most university and college campuses in the US Universities built new basketball arenas such as the Palestra at the University of Pennsylvania (built in 1927) and Cameron Indoor Stadium at Duke University (built in 1940).

American campuses experienced radical change and expansion between the World Wars. Large purpose-built buildings and Beaux Arts inspired quadrangles were built at nearly every major American university. Buildings were built to last at least 100 years and were constructed out of concrete, brick and/or stone. After the First World War, major American universities experienced unprecedented growth and utilised systemised, economic and science-based ideas for campus planning. Smaller campus buildings were arranged together as single units of building construction. This methodology of planned development on the campus incorporated more precise scheduling and financial planning means for the large-scale capital projects at all the major US public and private universities and it allowed a better economic use of building materials and a more cohesive appearance in campus design (O’Donnell 1929). Universities implemented master plans for expansion and built campus buildings in a single unified style that epitomised a university's symbolic aspirations. The University of Chicago built out their campus in a collegiate Gothic style to spiritually align it with ancient stone British universities, Oxford and Cambridge. Yale and Princeton kept their Colonial campuses but also mimicked the ancient British university ideal, this was especially the case at Yale, most notably, in building the Harkness, or Memorial, Quadrangle, designed by James Gamble Rogers. Harvard, Brown University, and Dartmouth College embraced their colonial heritage and perpetuated their red brick tradition. Universities of North Carolina, Illinois, Kentucky, Maryland, and Johns Hopkins University also chose to emulate the American colonial ideal. Regional expression of 'Collegiate Gothic' and 'Collegiate Georgian' emerged on certain campuses. The University of Oklahoma built their campus in a 'Prairie Gothic', the University of Florida built their campus in a 'Tropical Gothic' style. Leland Stanford envisioned the campus for the university he dedicated to his son's memory, built in a California version of the Romanesque style. Oklahoma State College (now university) built their iconic buildings in a 'Prairie Georgian' manner. But it was benefactor James Buchanan Duke who built his campus, originally Trinity College and renamed Duke University in 1924, in both the Gothic and Georgian styles; the West Campus in the stone English Gothic style and the East Campus in the Jeffersonian red brick Georgian style.

The early $20^{\text {th }}$ century experienced a period of extensive 

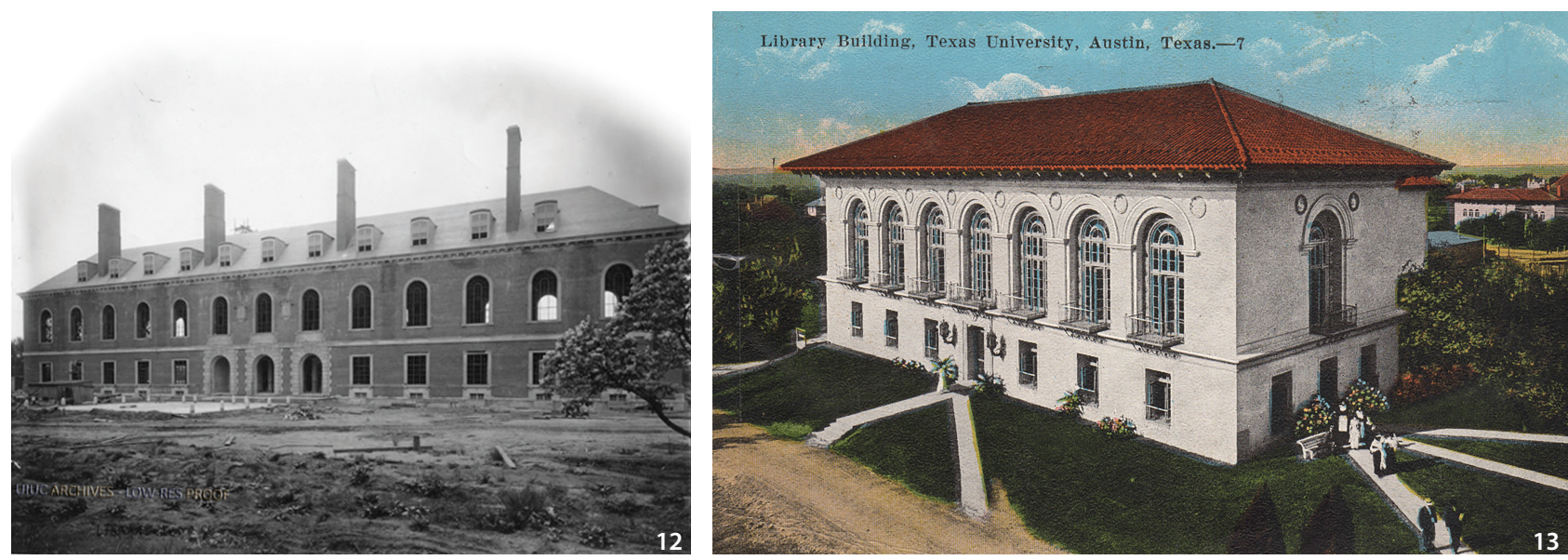

Figure 12 University of Illinois Library, under construction, Urbana, Illinois, 1927 (Source: University of Illinois Archives, Urbana, Illinois). Figure 13 University of Texas Library, Austin, Texas, c 1910 (Source: University of Texas Archives, Austin, Texas).

building of libraries on campuses. Beginning in late $19^{\text {th }}$ century with the founding of the American Library Association by Melvil Dewey, published information management became more systemised; this change determined how libraries were to be organised. The architecture of libraries began to reflect this change of management, beginning with the Boston Public Library by McKim, Mead and White in 1888, which was based on the design of the Bibliothèque Nationale in Paris. American philanthropist Andrew Carnegie funded libraries at numerous American universities, beginning with the library at the university he founded in his hometown of Pittsburgh, Pennsylvania, Carnegie Institute of Technology (now Carnegie Mellon University) among dozens of other universities libraries (Kaser 1997).

Enrollment and curricular growth after the First World War accelerated the trend at American universities to build large, expandable, highly specialised libraries. By 1916, at the University of Illinois, both the university administration and the state legislature set the goal for the university library to have one million volumes of books in it by 1930 . Already faculty and students were frustrated with the outdated library facility, which they considered 'hopelessly congested and deplorably overcrowded'. In 1921, as Illinois was already undergoing its largest building expansion period in its history, university-hired architect Charles Platt was commissioned to design the new library. Platt designed it to harmoniously blend with the prevailing campus building style (which he determined earlier), the 'Colligate Georgian'; it featured an elaborate entry hall, grand staircase, reference room, and three large reading rooms. The University of Illinois Main Library was designed to be built in multiple phases centred around a six-story tall solid masonry and concrete book stack block. Similar library buildings were built at all the major US universities, such as: Harvard, Yale, Columbia, Cornell, the University of Chicago, Texas, California-Berkeley, and Michigan, to name only a few. Each of these university libraries were designed based on lessons learned in the design and construction of major urban libraries, which were built throughout the US in cities like, New York, Boston, Detroit, St. Louis, and San Francisco. They were the product of a continuing evolution in both architecture and library science and they would come to symbolise the true power and prestige of American universities-places of knowledge generation and dissemination (Figure 12, Figure 13).

The development of the modern American university library was the result of three factors: a deliberate motive to increase the size of book collections at each American university; a significant increase in student enrolment and the newly developed teaching style that emerged at American universities. Increasing the size of collections reflected both the expanding comprehensive nature of education practices in the US and the popular metric for determining the reputation and prestige for all American universities. In other words, the larger the library, the more prestigious the university. With the passage and implementation of the Morrill Land Grant Act, more Americans than ever before were attending universities. During the first three decades of the $20^{\text {th }}$ century, states, like Illinois, made it a priority to provide every opportunity for young people to earn a university degree. At this time, American universities began to employ 'the seminar method' of teaching, which required students to consult multiple sources, both primary and secondary. This new teaching method required libraries to sequester books by subject to allow ease of research by both students and scholars. Increased collections, 


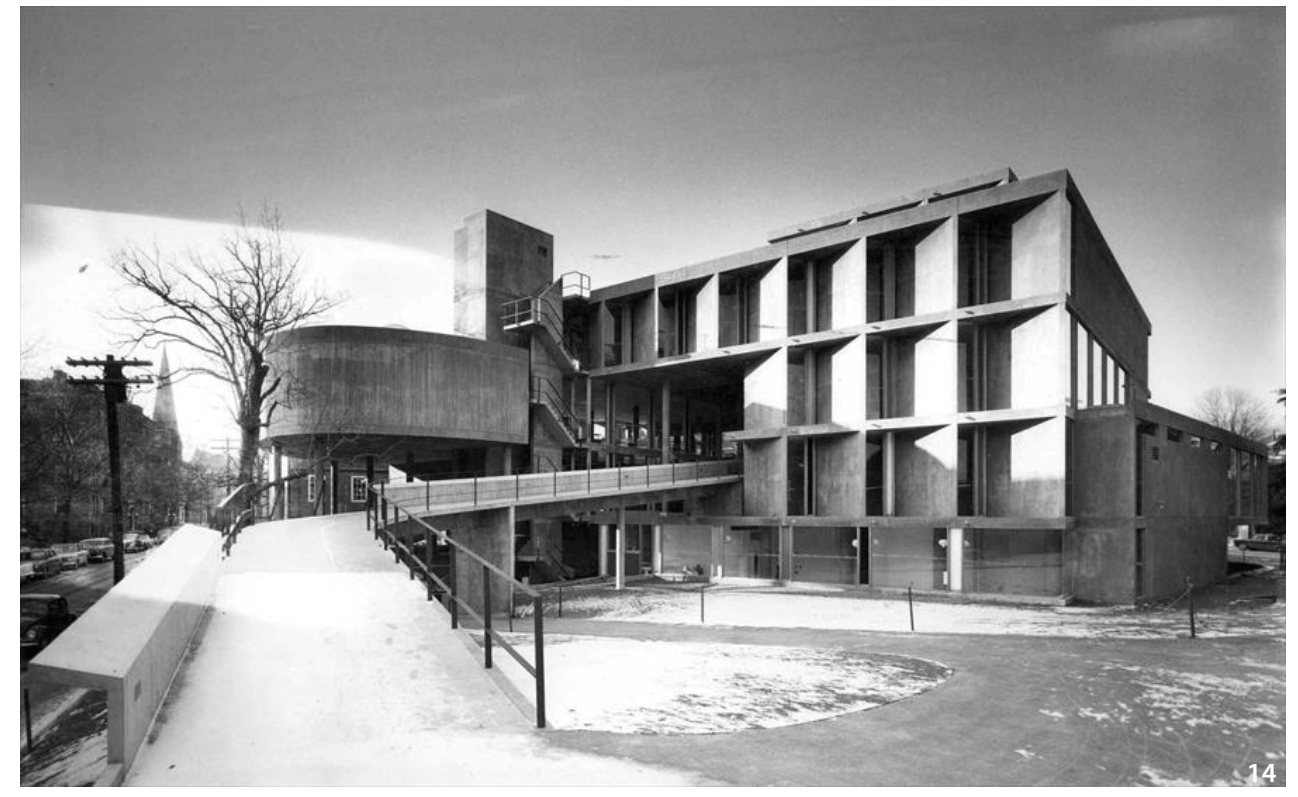

Figure 14 Carpenter Centre, Harvard University, Cambridge, Massachusetts, Le Corbusier, Architect (Source: Harvard University Archives) . organised by subject, along with increased enrollment, profoundly changed the nature of planning and building university libraries, which made older libraries, like Jefferson's Rotunda, obsolete (Peoples 2011).

\section{Modern Architecture and the American University Campus}

The post-World War II period ushered sweeping changes in university campus design in the US Modern architecture challenged the authority of stylistic standards, which had been implemented during the 1920s and 1930s of university campus building design, be it: Neo-classical, Collegiate Gothic Revival, or Collegiate Georgian Revival. The Servicemen's Readjustment Act of 1944, popularly known as the G. I. Bill, allowed millions of young men, who recently served in World War II, to attend American universities. This resulted in a dramatic student enrolment in all universities, which was followed 20 years later with the 'Baby Boom' generation enrolment. By the mid- $20^{\text {th }}$ century, university campuses grew exponentially and new architecture forms, specifically Modernism, became pervasive on them.

In 1949, the German modern master architect, Ludwig Mies Van der Rohe, designed the new campus of the Illinois Institute of Technology in Chicago. Although laid out in a Beaux Arts format, consisting of quadrangles and axial gestures, the buildings were built in Mies' distinctive glass and steel International Style. The most significant building, which housed the Department of Architecture, Crown Hall, epitomised Mies' ideas of open planning. The
Chicago firm, Skidmore, Ownings, and Merrill, was significantly influenced by Mies and built a similar campus for the US Air Force Academy in Colorado Springs, Colorado in 1956. When modern campuses were built in an ensemble manner, the cohesion of the style provided the identity (one of modernity) for a university but when modern buildings were placed within the historic context of an established university campus, it made a striking difference that, at best, was provocative, and, at worse, jarring. Le Corbusier's Carpenter Centre for the Visual Arts at Harvard demonstrates the former statement, providing an interesting visual piece to the campus and a unique way to experience it (Figure 14). I. M. Pei's Johnson Museum of Art at Cornell incompatibly sits within the Second Empire, Victorian-era Arts Quadrangle. Throughout the US, university administrations deliberately set out to make a statement of progressivism and artistic avant-garde expressionism during the second half of the $20^{\text {th }}$ century and thereby making the American university campus one of the most accessible settings to experience high art modern architecture for Americans.

The modern period in campus design also brought about a rejection of master planning as a process for campuses and universities. In 1949, Joseph Hudnut, then dean of the Harvard School of Design, spoke out against campus master planning. He considered the concept 'grand compositions corseting the body of a live and unpredictable creature'. Hudnut proposed, 'flexible development' based on principles of growth that is open to change, as an alternative to master planning (Office of the University, Architect University of Virginia 2007). 
With this paradigm shift in the overall perception of campus planning and the prevalence of the automobile on American campuses, universities became more spread out, developing more land around them and thus becoming less visually cohesive. Sprawl, both on and off campuses, became a common occurrence and continues to be a problem on American campuses today. The result was often the building of more surface automobile parking lots or automobile parking structures. This condition caused expansion of the university into the town where they resided. Displacement of people and demolition of residential and small commercial privately-owned buildings caused strife between university leaders and townspeople.

\section{The Return to Campus Design and the Conservation of Historic Monuments at American University Campuses}

During the last two decades of the $20^{\text {th }}$ century, administrators, faculty, and students questioned Hudnut's approach, which had been applied during the 1960s and 1970s. New Urbanism, an urban design movement that promotes walkable and environmentally friendly habitations and celebrate local architecture, history, climate, and building practices, was implemented in campus planning and design in lieu of planning-based Modernism. The 'grand composition' approach to campus planning, which Hudnut despised, returned to the forefront of campus facilities planning. By the 1990s, campuses, such as the Universities of Miami and Notre Dame, planned new buildings and landscapes in the more Beaux Arts approach, which was more the norm a century earlier. Also during this time, a new awareness and appreciation for heritage architecture of a university campus emerged. Beginning with the celebration of the nation's bicentennial in 1976, older American universities began to take note of their historic monuments. Up to that point, most universities viewed their oldest buildings as outdated and no longer useful physical assets to the campus and the university mission. Often, historic buildings and monuments remained because universities did not have to the financial resources during the 1950s and 1960s to demolish them. In the mid 1960s, Americans reacted strongly against the wholescale demolition of monuments and historic quarters of cities. Historic preservation became an accepted approach in the US and was legitimised with the passage of the National Historic Preservation Act of 1966. But the realisation to conserve historic buildings and grounds at many American universities remained an elusive goal.
The first concerted effort to preserve the built patrimony of a historic American campus occurred at the University of Virginia, when a professional conservation architect was hired to restore the Jeffersonian buildings in 1982 . Other universities soon followed, such as Columbia and Harvard. Iconic buildings, namely, the entire ensemble of Jefferson designed buildings at the University of Virginia were renovated. Some of these buildings were restored to a significant historical date or setting, i.e. a historical moment in the university's history, like the American Civil War at the University of Alabama, or when a significant historical individual attended the university, i.e. Edgar Allen Poe's room during his tenure at the University of Virginia (Office of the University, Architect University of Virginia 2007).

In 2002, the Getty Foundation developed the Getty Campus Preservation Grant Program in which they awarded significant amounts of grant funding to universities for the intent to develop conservation master planning documents. The Getty Foundation funded over 100 projects. Projects included the complete campus conservation master plans for the University of Tennessee and Louisiana State University and more specific conservation planning projects, such as the historic landscape preservation master plan for California-Berkley and the window restoration planning project at Columbia ('SCUP Cybrary Resource Portal-Home' 2017).

The Getty Campus Preservation Program ended the program in 2007 and it was considered a great success. Through this 15-year period (2000-2015) of architecture and landscape architecture restoration work on historic university campuses, preservationists and conservationists recognised that the historic sections of American university campuses were not static entities to be preserved intact, as an outdoor historic site museum, but rather a living and dynamic environment for teaching and research, the primary component of any American university's mission. Historic buildings, such as the Campus YMCA at the University of North Carolina (originally built as a chapel with classrooms), were adapted into classrooms and meeting rooms for the University in 2007. In 2008, the University of Chicago purchased the old Chicago Seminary Building and renovated it into the new home for the Department of Economics in 2014 (Kamin 2017).

During the first two decades of the $21^{\text {st }}$ century, restoring historic campus buildings proved to be very beneficial to American universities. Whatever the motive, be it: the history of a university; the craftsmanship found in $19^{\text {th }}$ and early $20^{\text {th }}$ century campus architecture; the very 
mature and established landscapes, marketing the university; or the historic monuments that celebrated important moments for past students; conserving the historic built patrimony proved to be a rewarding endeavour at American universities. Both the university community and visitors enjoyed experiencing these restored buildings and monuments (Godschalk and Howes 2012).

Environmental sustainability had also become a primary objective in campus design and construction in the $21^{\text {st }}$ century. For the past 20 years, environmentally sensitive design, primarily in the areas of water and energy conservation, was implemented in campus planning. Climate change, caused by carbon dioxide emissions, prompted university presidents across the US to pledge that they will reduced their campuses carbon emissions 80 percent by 2050 (Second Nature 2017). Universities throughout the US began buildings that conform to the standards set by Leadership in Energy and Environment Design (LEED) program, established by the US Green Building Council (USGBC 2017). Numerous universities have committed to this environmentally friendly aspiration. Stanford University built the Knight Management Centre as an indooroutdoor complex with solar panels mounted on the roof of the buildings and naturally ventilated indoor spaces (Sfgate 2017). Conservation of potable water, along with managing stormwater runoff from new building sites to their pre-development levels, prompted the US Environmental Protection Agency to sponsor 'the Campus RainWorks Challenge Competition'. In the 2016 competition, Kansas State University won first place with its new rain garden park, which released filtered stormwater back into tributary streams, while also providing a new recreational space for the community (EPA 2017).

Today, American university campuses, whether urban, suburban, or rural in context, are, for the most part, cities upon themselves. They are comprised of physical settings-residential, teaching, research, and recreational, -and complex networks of transportation, utilities, and landscapes (Dober 2000). They have and always will be purpose-driven places for teaching and research for institutions that serve both the US and the entire world. It is an urban typology that is very adaptable and embedded with high philosophical values, that were conveyed on them by their founders and the communities that use them. As technology and pedagogy continue to change and evolve, the physical nature of the American university campus will continue to evolve to meet future challenges of the global society.

\section{Exporting the American Campus Idea to the World}

Throughout the early $20^{\text {th }}$ century and up until today, the architecture and planning of the American university has profoundly influenced the architecture of higher education at universities throughout the world. This architectural experiment rooted the making and conveying of knowledge with place. In each of its milestone designs, reflecting the social trends that drive society, the American campus has united powerful visual themes with intellectual ideas. This is what has made it a designed work for the procurement of knowledge and a cultural artifact. Expert architects and educators from Asia, Europe, Africa, and Australia have studied this uniquely American architectural typology and replicated it in their own country. Even as the American university campus developed, ideas of it from the US, specifically how it continued to evolve, were learned by visiting designers and then transplanted in other countries.

It is indeed ironic that a century and a half after American colonists, and later on, American citizens looked to Oxford and Cambridge in the UK for inspiration to build their campuses that British educators and architects came to the US to draw inspiration from the American university. By 1880 , industrialised Britain had evolved past the medieval model of university education (the Ancient Universities'-Oxford, Cambridge, St. Andrews, Glasgow, Aberdeen, Edinburgh, and Durham). Growing industrialised cities: Birmingham, Manchester, Liverpool, Sheffield, and even London, sought to build modern new universities that were civic in purpose and research-based. From various declarations from the British Parliament, 'Redbrick' universities were founded and their physical form was inspired by the American university campus model.

In 1899, a group of faculty members from Birmingham toured Harvard, Toronto, Johns Hopkins, Cornell, and MIT to understand how the campus of the new University of Birmingham would both look and work. In 1901, inaugural chancellor and politician Joseph Chamberlain consulted Andrew Carnegie regarding the architecture of the new university. Through the faculty tours across North America and Carnegie recommendations, the University of Birmingham administration decided that the campus form for their university, specifically within the engineering college, should follow the example set by Cornell University. Following Carnegie's recommendations to Chamberlain, a grand bell tower was built in the centre of the campus, similar in form and function to Cornell's McGraw Tower. The Joseph Chamberlain Memorial Bell Tower, 


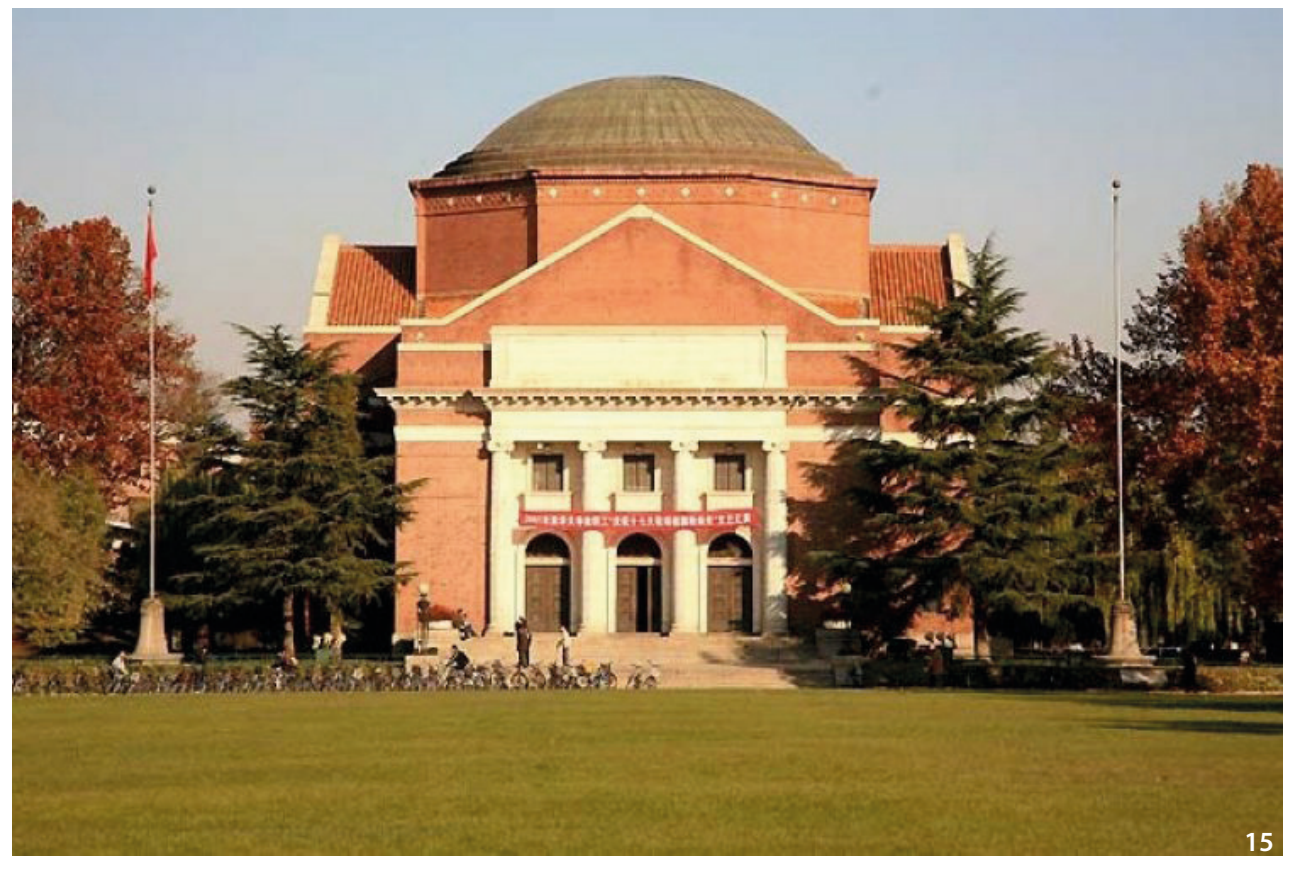

Figure 15 Great Auditorium, Tsinghua University, Beijing, China. Henry Murphy, Design Architect, Tsin Chuang, Supervising Architect (Source: the author). commonly known as 'Old Joe', is the tallest masonry tower in Britain, taller than 'Big Ben' at the Palace of Westminster (Whyte 2015, 15-135). Other redbrick universities, such as, Newcastle, Sheffield, Bristol, and Manchester, also based their campus designs on North American universities.

During the autumn of 1927, a Spanish delegation, led by architect Modesto Lopez Otero, embarked on a tour for inspiration in designing what would become the first campus constructed on the European continent, the University City of Madrid. Intended to house the semi-autonomous schools, Medicine, Sciences, and Pharmacy, its benefactor, King Alfonso XIII, envisioned it to be a 'utopian' city, where students and professors would live and knowledge produced and taught. Learning from North American universities was an idea promoted by the King's confidant (and dentist), Florestán Aguilar (Viscount of Casa Aguilar), who had been educated in the US, collected numerous campus plans of American universities, most notably, the proposed campus for Washington University in St. Louis, and had developed a supportive relationship with the Rockefeller Foundation. With the support of the King and the leading American philanthropic organisation, the architects set off to New York. They examined universities, mainly on the US east coast and in Canada: New York (Columbia and Princeton in New Jersey), New Haven, Connecticut (Yale), Boston (Harvard, MIT), Montreal (McGill University), Toronto (University of Toronto), Ann Arbor, Michigan (University of Michigan), Rochester (RIT), and the Washington, DC area (University of Virginia, Georgetown University, and Johns Hopkins University). Through their travels they experienced the diversity of forms and functions that epitomised American campuses (Campos Calvo-Sotelo 2006).

At Yale, they witnessed the all-inclusive moralistic pedagogy_religious, intellectual, physical, and moral-that was embedded in Ivy League universities. While on the campuses of more modern universities, such as MIT and Michigan, they experienced the campus architecture (laboratories, testing fields, specimen and materials libraries), influenced by an industrial-based pedagogy. It is worth noting that planners in Britain and Spain received financial support and intellectual influence from American philanthropy: the Carnegie Foundation in Britain and the Rockefeller Foundation in Spain. American philanthropy supported campus architecture in the US from the beginning and, recently, has been a leader in its conservation (Campos Calvo-Sotelo 2006 and Whyte 2015).

Europeans were not the only ones who were inspired by US campus architecture, Chinese architects also learned from it and transplanted it in their native land. In 1914, Tsin Chuang graduated from the University of Illinois with a degree in architecture. After returning to his native China, he assisted (as assistant superintendent for buildings) Henry Murphy, the noted American architect, in designing the main auditorium building and the main landscape for Beijing's Tsinghua University. The most notable designs were a large grassy academic quadrangle (a rarity in congested Beijing) and the grand auditorium, based on the University of Illinois' Foellinger Hall. The 
rotunda configured auditorium, facing the large grassy and wooded quadrangle, harkens back to Jefferson's vision of the American university, 'the academical village', where knowledge is generated and disseminated for the citizens of the country. This uniquely American architectural form, which is not completely urban and not completely suburban or rural, has become the model throughout the world for building complexes for university education and research. Working with American Charles Lane, the superintendent for construction, Chuang procured both American and Chinese materials and elements in building the campus. When Murphy returned to Beijing in 1918, he described the built work as 'thrillingly satisfactory'. (Cody 2001, 61-68; Chen 2014) (Figure 15).

\section{Conclusion}

What has made the American university campus a designed work that produced knowledge and became an artefact of cultural heritage is that it is rooted in place and circumstance. Regional architecture and social ideas along with historical moments, such as the founding of the Republic and the Morrill Act brought about profound transformations to the campus idea. But what is important to acknowledge in understanding the campus as a cultural heritage artefact is that it is a community based on the social, intellectual, and aesthetics trends that drive society today.

Because they were first conceived and later sustained to be places where knowledge is generated and values expressed, there is no other architectural concept conceived in North America with greater care than the university campus. They embody what we aspire as the higher purposes of our society. This is why great care should be placed on conserving them as cultural artefacts.

Sprawl, new technology, new pedagogy, and everincreasing enrolment will challenge the historic and aesthetic integrity of campuses. Fortunately, most universities now recognise that their campus is a unique expression, created by significant events, thereby crafting a distinctive sense of place. The challenge will always be to strike the balance: conserve the artefact while allowing it to continue to generate and teach knowledge.

\section{References}

Alcott, John, V. 1986. The Campus at Chapel Hill: Two Hundred Years of Architecture. Chapel Hill: The Chapel Hill Historical Society.

Bryan, John, Morrill. 1976. An Architectural History of the
South Carolina College. Columbia: University of South Carolina Press.

Campos Calvo-Sotelo, Pablo. 2006. The Journey of Utopia: The Story of the First American Style Campus in Europe. Translated and edited by Joan Martha Costello. New York: Nova Science Publishers, Inc.

Chen, Jodi. 2014. "University of Illinois has 100-year History of Interaction with China," The Chicago Tribune, August 1. Accessed 10 October 2017 http://www.chicagotribune.com/news/nationworld/ct-university-ofillinois-chinese-students-d1side-20140801-story.html

Cody, Jeffrey W. 2001. Building in China: Henry K. Murphy's Adaptive Architecture, 1914-1935. Seattle, WA: University of Washington Press.

Coates, Albert and Gladys Hall Coates. 1985. The Story of Student Government in the University of North Carolina at Chapel Hill. Chapel Hill: Professor Emeritus Fund.

Dober, Richard P. 2000. Campus Landscapes: Functions, Forms, Features 1st ed. New York: Wiley Publishing.

EPA (Environmental Protection Agency). 2017. “Campus Rain Works 2017: A Green Infrastructure Design Challenge for Colleges and Universities." https://www. epa.gov/sites/production/files/2017-10/documents/ competition_brief_-final_508.revised.0.pdf

Godschalk, David R., and Jonathan B. Howes. 2012. The Dynamic Decade: Creating the Sustainable Campus for the University of North Carolina at Chapel Hill, 20012011. Chapel Hill: University of North Carolina Press.

Harvard University. 2016. "Harvard Stadium Football History.” Accessed 6 September 2016. http://www.gocrimson.com/information/facilities/Harvard_Stadium_ Football_History

Jefferson, Thomas to L.W. Tazwell Correspondence, 5 January 1805, Thomas Jefferson Papers, Manuscripts Department, University of Virginia Library, Charlottesville, VA.

Kamin, Blair. 2017. "Chicago Seminary Rebirth: A Sophisticated Mix of Old, New." Chicagotribune.Com. Accessed 1 December 2017. http://www.chicagotribune. com/news/columnists/ct-chicago-seminary-renovation-karmin-met-20141123-column.html

Kapp, Paul H. 2015. The Architecture of William Nichols: Building the Antebellum South in North Carolina, Alabama, and Mississippi. Jackson: University Press of Mississippi.

Kaser, David. 1997. The Evolution of the American Library Building. Lanham: Scarecrow Press.

Kornwolf, James. 1989. "So Good A Design” Williamsburg, 
VA: The College of William and Mary Joseph and Margaret Muscarelle Museum of Art, 1989, 32, 72-75.

Kraus, Joe W. 1961. “The Development of a Curriculum in the Early American Colleges." History of Education Quarterly 1 (2): 64-76.

Kruty, Paul. 1990. "Nathan Clifford Ricker: Establishing Architecture at University of Illinois." In No Boundaries: University of Illinois Vignettes, edited by Lillian Hoddeson, 3-14. Urbana, IL: University of Illinois Press.

O’Donnell, Thomas E. 1929. “The University of Illinois Campus Plan," The Western Architect March.

Office of the University Architect, University of Virginia, “2007 University of Virginia Historic Preservation Framework Plan.” Accessed 7 September 2016. http:// www.officearchitect.virginia.edu/pdfs/HistoricPreservationFrameworkPlan.pdf

Parsons, Kermit C. 1968. The Cornell Campus: A History of Its Planning and Development. New York: Cornell University Press.

Peck, Amelia. 1992. Alexander Jackson Davis: American Architect 1803-1892. New York: Rizzoli Press.

Peoples, Brock. 2011. "A Great Library on the Prairie: The History, Design, and Growth of the University of Illinois Library." Library Trends 60 (1): 134-151.

Pierson, Jr. William Jr. 1970. American Buildings and Their Architects, Volume 1: The Colonial and Neoclassical Styles. New York: Oxford University Press.

Purini, Franco. 1984. La Arquitectura Didáctica. Murcia: Aparejadores y Arquitectos Técnicos de Murcia.

Quincy, Josiah. 1860. A History of Harvard University, Vol. 1. Boston: Nichols, Lee \& Co.

Getty. 2017. "SCUP CYBRARY Online Resource PortalHome.” Accessed 30 November 2017. Scup.Org. http:// getty.scup.org/index.php?P=Home\&ResourceOffs et $=78$.

Second Nature. 2017. “The Presidents' Climate Leadership Commitments -Second Nature 2017.” Accessed 29 May 2017. http://secondnature.org/climate-guidance/ the -commitments/.

Sfgate. 2017. "Stanford Must Hold Architecture to Higher Standard.” Accessed 26 May 2017. http:// www.sfgate.com/bayarea/place/article/Stanfordmust-hold-architecture-to-higher-standard-2308253. php\#photo-1813949

Patrick Sisson. 2017. "Where History Meets the Future; The Unfinished Master Plan of Tougaloo College." Accessed 9 October 2017. https://www.curbed.com/2015/7/15/9940596/ tougaloo-gunnar-birkerts-campus-masterplan
Turner, Paul V., Marcia E. Vetrocq, and Karen J. Weitze. 1976. The Founders and the Architects: The Design of Stanford University. Stanford: Department of Art, Stanford University.

University of California at Davis, "About UC Davis and Our Alumni." Accessed 6 September 2016. http://alumni.ucdavis.edu/about-us/alumni-stats/

US Green Building Council. "US Green Building Council 2017," http://www.usgbc.org. Accessed 28 May 2017.

Whyte, William. 2015. Redbrick: A Social and Architectural History of Britain's Civic Universities. Oxford: Oxford University Press.

Wilson, Richard Guy. 2009. Thomas Jefferson's Academical Village: The Creation of an Architectural Masterpiece. Charlottesville: University of Virginia Press.

Woods, Mary N. 1985. "Thomas Jefferson and the University of Virginia: Planning the Academic Village." Journal of Architectural Historians 44 (3): 266-283. 